В.М. Чепела, О.М. Новомодний, І.М. Коржов, О.І. Колбасін

Державне підприємство "Харківський регіональний науково-виробничий центр стандартизачії, метрології та сертифікації” (ДП “Харківстандартметрологія”), Харків

\title{
АНАЛІЗ ПОТОЧНОГО СТАНУ ТА ДИНАМІКИ РОБІТ КАЛІБРУВАЛЬНИХ ЛАБОРАТОРІЙ УКРАЇНИ
}

В статті наведено узагальнені результати поточного стану та динаміки робіт калібрувальних лабораторій Украӥни. Розглянуто діяльність Метрологічного иентра Державного підприємства "Харківський регіональний науково-виробничий центр стандартизаиії, метрологї та сертифікації”" (МЦ ДП “Харківстандартметрологія”) - першого в Україні акредитованого на відповідність EN ISO/IEC 17043 провайдера перевірки професійного рівня. Наведено узагальнені результати перевірки професійного рівня учасників більше ста раундів, участь в яких прийняли участь більше трьохсот n'ятдесяти учасників від більше ніж тридияти п'яти організацій різної форми власності. Проведено аналіз структури завершених раундів та їх учасників за роками і видами вимірювань.

Ключові слова: перевірка професійного рівня, провайдер перевірки професійного рівня, EN ISO/IEC 17043, калібрування.

\section{Вступ}

Постановка проблеми. За минулий час було накопичено певний досвід у сфері перевірки професійного рівня калібрувальних лабораторій [1-5] та виникла необхідність в розгорнутому аналізі поточного стану та динаміки робіт з перевірки професійного рівня серед калібрувальних лабораторій України.

Аналіз останніх досліджень і публікацій. Актуальність, необхідність, технічні аспекти, особливості проведення перевірки професійного рівня послуг, які надаються калібрувальними лабораторіями, загально визнані та прийняті, а також розглянуті у багатьох публікаціях, зокрема у [1-5].

Досвід діяльності і сталої практики таких міжнародних організацій як ILAC, Eurachem, EUROLAB, EA, APLAC тощо, показує, що саме перевірка професійного рівня зі застосуванням міжлабораторних порівнянь $\epsilon$ найбільш раціональним методом перевірки технічної компетентності калібрувальних та вимірювальних лабораторій [1 - 5].

Зважаючи на таке беззаперечне визнання світовою метрологічною спільнотою значущості перевірки професійного рівня для забезпечення єдності вимірювань, з урахуванням орієнтації вітчизняного виробника та економіки на Свропейський ринок, прийняття стратегії розвитку держави МЦ ДП “Харківстандартметрологія” у 2016 році приступив до реалізації складного та нового напрямку роботи - перевірка професійного рівня за вимогами міжнародного стандарту EN ISO/IEC 17043 [6], орієнтуючись, в першу чергу, на потреби споживачів послуг з калібрування та калібрувальних лабораторій, акредитованих на відповідність ISO/IEC 17025 [7] з урахуванням положень політики Національного агентства 3 акредитації України (НААУ) [8].
Накопичений практичний досвід у проведенні перевірки професійного рівня дозволив МЦ ДП “Харківстандартметрологія” першим в Україні в 2018 році пройти процедуру акредитації в НАAУ на відповідність EN ISO/IEC 17043 [6] та отримати атестат про акредитацію № 50003 від 03 грудня 2018 року [9-10].

Поява акредитованих провайдерів перевірки професійного рівня має величезне значення як для НААУ, так і для калібрувальних лабораторій. У певному сенсі, провайдер перевірки професійного рівня займає позицію між органом акредитації (НААУ), калібрувальними лабораторіями та замовниками послуг 3 калібрування. Провайдер перевірки професійного рівня оцінює технічну компетентність калібрувальної лабораторій, що дає змогу експертам НААУ, керівництву калібрувальної лабораторії та замовникам послуг з калібрування бути впевненими у спроможності калібрувальної лабораторії надавати якісні з технічної точки зору, метрологічні послуги 3 калібрування засобів вимірювальної техніки.

Участь у раундах перевірки професійного рівня $\epsilon$ не тільки необхідною умовою відповідності лабоpaторії ISO/IEC 17025 [7], але й найефективнішим інструментом із зовнішньої оцінки якості метрологічних робіт. Регулярна участь калібрувальної лабораторії у раундах перевірки професійного рівня, що проводить акредитований провайдер, дає змогу не тільки поліпшити процедуру акредитації та контролювати свою технічну компетентність, але й зменшити ризики та попередити появу “неякісних послуг” з технічної точки зору. Також позитивні результати участі у раундах перевірки професійного рівня підвищують довіру до надаваних метрологічних послуг, та можуть слугувати одним 3 факторів, 
що впливає на вибір калібрувальної лабораторії замовниками метрологічних послуг.

Мета статті полягає в представленні метрологічній спільноті результатів діяльності МЦ ДП “Харківстандартметрологія” у якості провайдера перевірки професійного рівня за п’ять років.

\section{Виклад основного матеріалу}

Станом на перший квартал року в Україні зареєстровано чотири акредитованих провайдера перевірки професійного рівня [10] серед яких МЦ ДП “Харківстандартметрологія” єдиний спеціалізується на проведенні перевірки професійного рівня калібрувальних лабораторій. Інші провайдери перевірки професійного рівня мають сферу акредитації, пов’язану з випробуваннями різного роду продукції.

МЦ ДП "Харківстандартметрологія” пропонує учасникам сім схем перевірки професійного рівня 3 калібрування за видами вимірювань, що наведені у табл. 1 [9].

Схеми перевірки професійного рівня

Таблиця 1

Назва схеми перевірки професійного рівня

MetrCentr-PT-C-L Дослідження засобів вимірювань довжини

MetrCentr-PТ-C-ЕМ Дослідження засобів вимірювань електричних та магнітних величин

MetrCentr-PТ-С-М Дослідження засобів вимірювань маси та пов'язаних $з$ нею величин

MetrCentr-PТ-С-Т Дослідження засобів вимірювань термометричних величин

MetrCentr-PT-C-QM Дослідження засобів вимірювань фізико-хімічних величин та кількості речовини

MetrCentr-PT-C-PR Дослідження засобів вимірювань фотометричних та радіометричних величин

MetrCentr-PT-C-TF Дослідження засобів вимірювань часу та частоти

Джерело: розроблено авторами за даними [9].

МЦ ДП “Харківстандартметрологія” проводить раунди схем перевірки професійного рівня як у сфеpi своєї акредитації, так і поза сферою, опановуючи нові напрямки, щоб задовольнити потреби замовників зазначених послуг. Якість робіт за новими напрямками забезпечена застосуванням підходів та вимог щодо організації та проведення перевірки професійного рівня, відповідно до положень та вимог стандарту EN ISO/IEC 17043 [6] та ISO 13528 [11]. Нові напрямки діяльності провайдера будуть заявлені при розширенні сфери акредитації. Процентне співвідношення кількостей проведених раундів
МЦ ДП “Харківстандартметрологія” до сфери акредитації наведено на рис. 1.

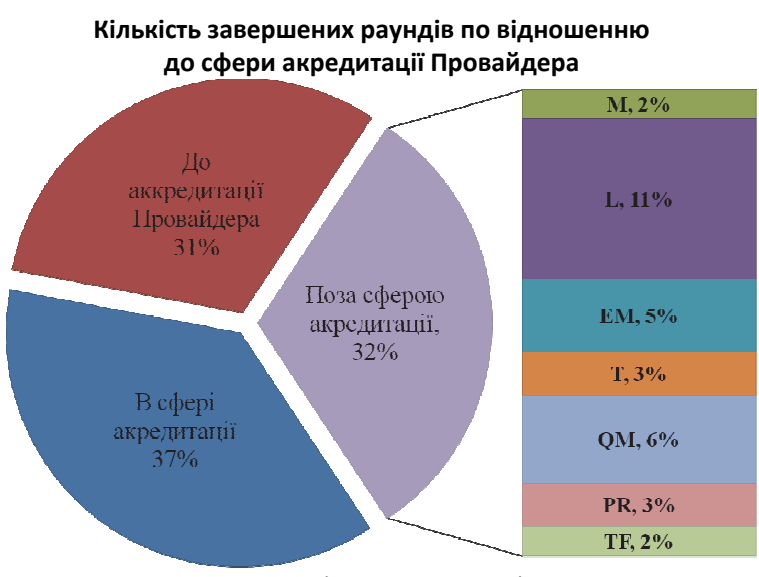

Рис. 1. Проведені раунди по відношенню до сфери акредитації провайдера перевірки професійного рівня

Джерело: розроблено авторами за даними [9-10].

До моменту подачі заявки на акредитацію МЦ ДП “Харківстандартметрологія” накопичив значний досвід у організації та проведенні робіт з перевірки професійного рівня: тридцять два раунди за майже три роки.

Слід зауважити, що за цей період замість стандарту ДСТУ EN ISO/IEC 17043:2014 (набрання чинності 01.01.2016) [12], який був виданий методом “Обкладинки”, було введено в дію національний стандарт ДСТУ EN ISO/IEC 17043:2017 (EN ISO/IEC 17043:2010; ISO/IEC 17043:2010, IDT) (набрання чинності 01.01.2018) [13], в якому змінився переклад 3 англійської мови деяких термінів, що внесло національний колорит у термінологію провайдера.

Також слід наголосити, що потреба в оцінюванні технічної компетенції калібрувальних лабораторій шляхом проведення міжлабораторних порівнянь в Україні виникла раніше за прийняття ДСТУ EN ISO/IEC 17043:2014 [12], про що неодноразово порушувалось питання та виносилися пропозиції на рівні керівництва ДП "Харківстандартметрологія" . Розуміючи важливість цього питання, керівництво ДП “Харківстандартметрологія” ще в 2014 - 2015 роках, тобто до набрання чинності в Україні першого варіанту стандарту ДСТУ EN ISO/IEC 17043:2014 (набрання чинності 01.01.2016) [12], проводило перемовини з НААУ про можливість створення тимчасових документів, на основі яких було б можливе проведення перевірки професійного рівня із застосуванням міжлабораторних порівнянь.

В цілому, не зважаючи на новизну послуги, складнощі у реалізації та становленні ринку послуг 3 калібрування [14-17], попит на проведення раундів динамічно зростає. Так, майже 32 \% від всіх проведених на сьогоднішній день раундів - це напрацювання досвіду у нових напрямках калібрування 3 
новими зразками поза сферою акредитації провайдера МЦ ДП “Харківстандартметрологія” .

Найбільшим попитом поза сферою акредитації на сьогоднішній день користуються раунди за такими видами вимірювання:

1) $\mathrm{L}$ - засоби вимірювання довжини (34,4 \%);

2) $\mathrm{QM} \mathrm{-} \mathrm{засоби} \mathrm{вимірювання} \mathrm{фізико-хімічних}$ величин та кількості речовини (18,8 \%);

3) ЕМ - засоби вимірювання електричних та магнітних величин (15,6 \%).

Також наявні пропозиції з боку замовників послуг з перевірки професійного рівня стосовно доповнення переліку схем перевірки професійного рівня Провайдера схемою за видом вимірювання AUV акустика, ультразвук і вібрація.

На рис. 2-3 представлено аналіз завершених раундів за видами вимірювання та роками. На рис. 4-5 представлені кількість учасників раундів схем перевірки професійного рівня у розрізі видів вимірювання та років.

На рис. 2 та 4 виділені:

-2016* - рік започаткування МЦ ДП “Харківстандартметрологія” як провайдера робіт з перевірки професійного рівня. В цей рік проведені лише три пробні раунди, основний час та зусилля були зосереджені на створення та доопрацюванні системи управління якістю та реалізації вимог EN ISO/IEC 17043 [6];

- 2021** - результати приведені лише за перший квартал року.

Станом на кінець третього кварталу 2021 року загальна кількість завершених раундів складає сто два, найбільша кількість завершених раундів за рік складає сорок шість у 2020 році. Невеликий спад кількості раундів у 2019 році можливо пояснити деякими затримками, пов'язаними 3 проведенням акредитації, що припала на кінець 2018 року, та значними трудовитратами на поліпшення внутрішніх процедур і розроблення зручних сучасних інформаційних інструментів для діяльності МЦ ДП “Харківстандартметрологія” як провайдера перевірки професійного рівня.

Найбільша частка завершених раундів припадає на такі види вимірювань (рис. 3):

1) $\mathrm{M}$ - засоби вимірювання маси та пов'язаних 3 нею величин (29\%);

2) L - засоби вимірювання довжини (20\%);

3) ЕМ - засоби вимірювання електричних та магнітних величин (17\%).

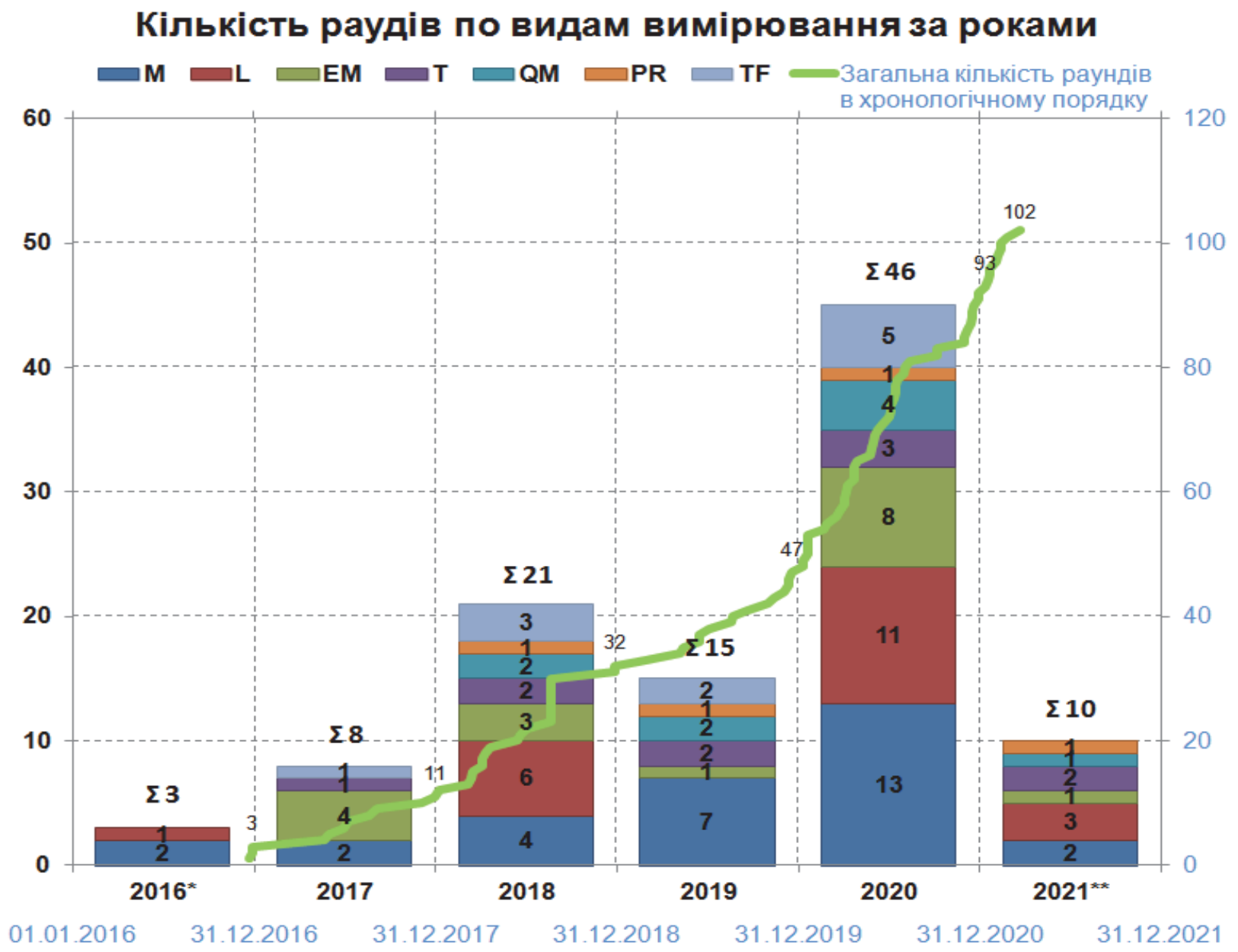

Рис. 2. Завершені раунди по видам вимірювання за роками Джерело: розроблено авторами за даними [9]. 


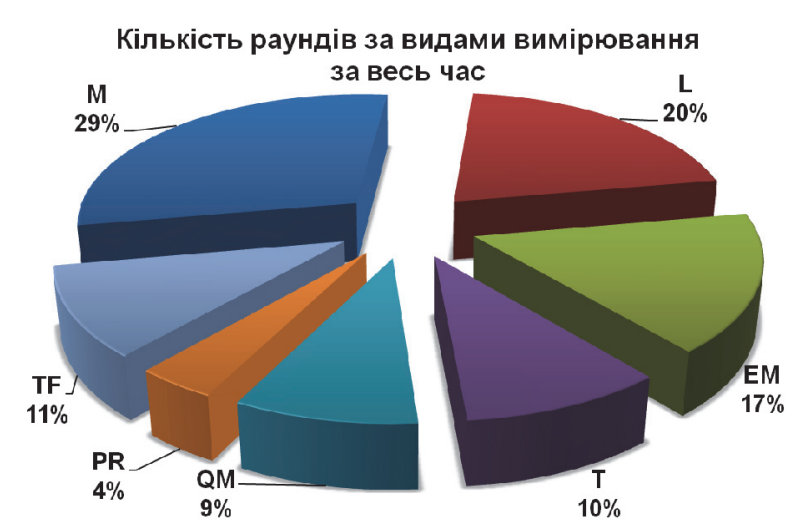

Рис. 3. Завершені раунди по видам вимірювання Джерело: розроблено авторами за даними [9].

Такий попит обумовлено різноманітністю категорій за цими видами вимірювань та великим парком засобів вимірювань, послуги 3 калібрування яких пропонують лабораторії у цих видах вимірювань. Статистика проведених раундів (рис. 4) відображає зростання кількості учасників схем перевірки професійного рівня за роками, і навіть “просадка" кількості раундів у 2019 році майже не відобразилось на сума- рній кількості учасників (71 у 15 раундах в 2019 році проти 72 у 21 раундах 2018 році). Також слід відмітити, що за перший квартал 2021 року кількість учасників майже досягла показників за 2018, 2019 років та більше половини кількості учасників 2020 року.

Найбільшим попитом серед учасників на сьогоднішній день (рис. 5) користуються раунди за видами вимірювання:

1) $\mathrm{M} \mathrm{-} \mathrm{засоби} \mathrm{вимірювання} \mathrm{маси} \mathrm{та} \mathrm{пов'язаних} 3$ нею величин (30 \%);

2) $\mathrm{L}$ - засоби вимірювання довжини (20\%);

3) Т - засоби вимірювання термометричних величин (15\%);

4) ЕМ - засоби вимірювання електричних та магнітних величин (15\%).

Ці дані у певній мірі корелюються 3 даними рис. 3 , за винятком виду вимірювання Т (засоби вимірювання термометричних величин), де частка по раундам - $10 \%$, а частка по учасникам - $15 \%$, що свідчить про вищу кількість (в середньому) учасників у раундах за цим видом вимірювання.

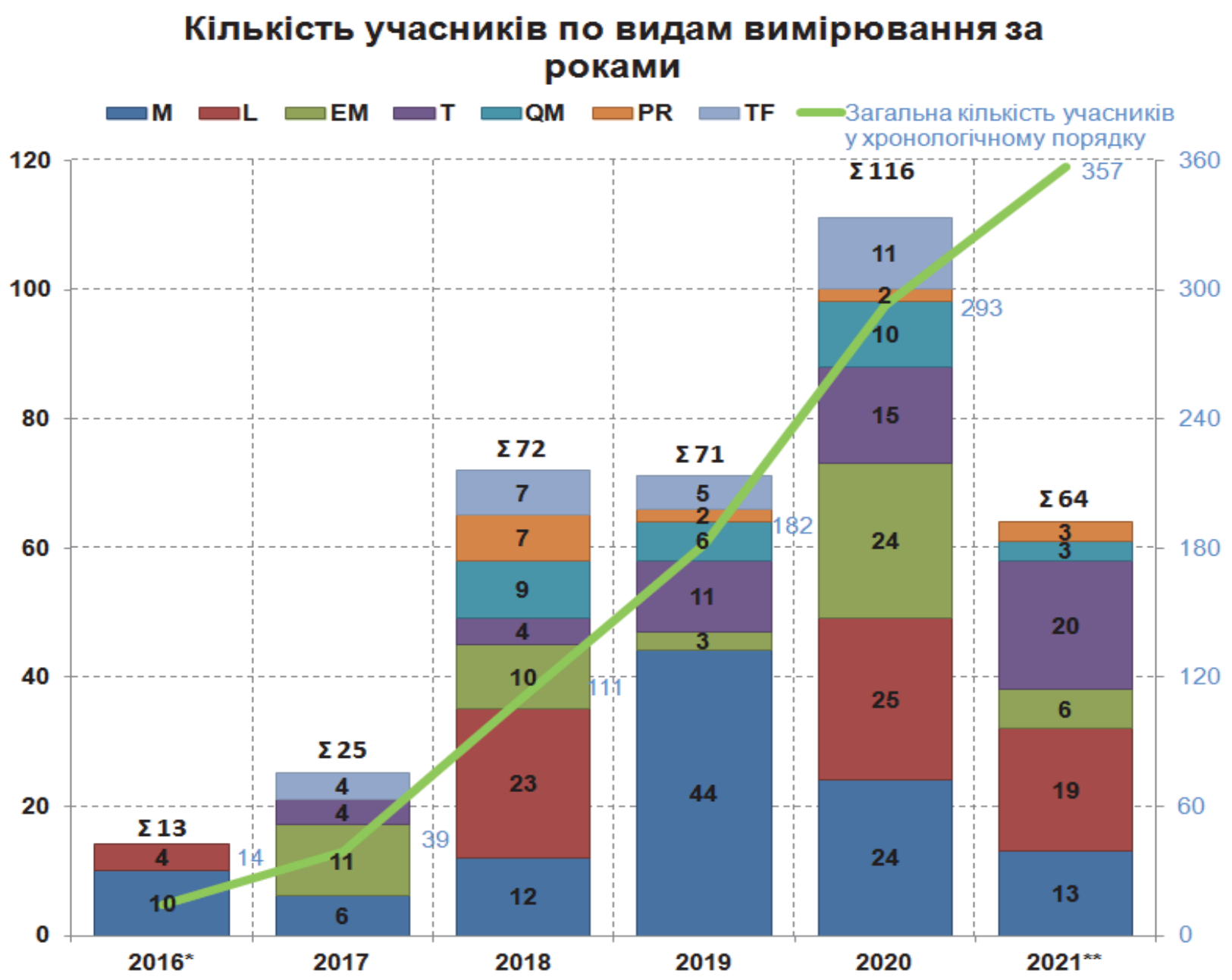

Рис. 4. Кількість учасників за роками та видами вимірювань Джерело: розроблено авторами за даними [9]. 


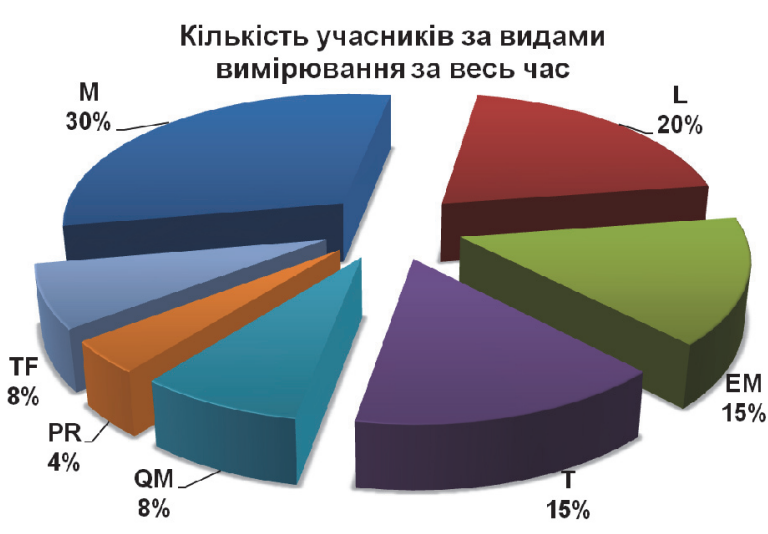

Рис. 5. Кількість учасників, що прийняли участь у раундах перевірки професійного рівня за видами вимірювання

Джерело: розроблено авторами за даними [9].

У той же час аналіз кількості організацій, що прийняли участь у раундах перевірки професійного рівня за видами вимірювань (рис. 6):

1) $\mathrm{M} \mathrm{-} \mathrm{засоби} \mathrm{вимірювання} \mathrm{маси} \mathrm{та} \mathrm{пов'язаних} 3$ нею величин (26 організацій);

2) Т - засоби вимірювання термометричних величин (25 організацій);

3) ЕМ - засоби вимірювання електричних та магнітних величин (20 організацій) свідчить про дещо іншу тенденцію.

При відносно великій кількості раундів та учасників за видом вимірювання L (засоби вимірювання довжини) кількість організацій-учасників відносно мала, і в той же час при невеликій кількості рау- ндів (10\%), але великій кількості учасників (15\%) за видом вимірювання Т (засоби вимірювання термометричних величин) кількість організацій (25) велика. Зазначений факт можливо тлумачити наступним чином: кількість організацій, які спеціалізуються на калібруванні засобів вимірювання довжини (L) відносно мала, але їх сфера діяльності більш різноманітна та потребує участі у великій кількості різних раундів перевірки професійного рівня, а організацій, які спеціалізуються на калібруванні засобів вимірювання термометричних величин (Т) досить багато, але їх сфера діяльності досить обмежена та уніфікована, тобто для підтвердження технічної компетенції необхідна участь у відносно малій кількості раундів перевірки професійного рівня.

Також слід звернути увагу на акредитаційний статус організацій, що приймають участь у раундах перевірки професійного рівня, що представлений на рис. 7. Акредитовані калібрувальні лабораторії згідно $з$ вимогами ISO/IEC 17025 [7] та політики НАAУ [8] зобов'язані приймати участь у перевірці професійного рівня. На момент написання статті в Україні згідно з реєстром акредитованих ООВ (органів оцінки відповідності) на офіційній web-сторінці НААУ акредитація дійсна для 35 калібрувальних лабораторій [10]. 3 них у раундах перевірки професійного рівня, проведених МЦ ДП “Харківстандартметрологія”, прийняли участь двадцять сім, тобто більше 77 \% від акредитованих НААУ калібрувальних лабораторій.

\section{Кількість організацій за видами вимірювання}

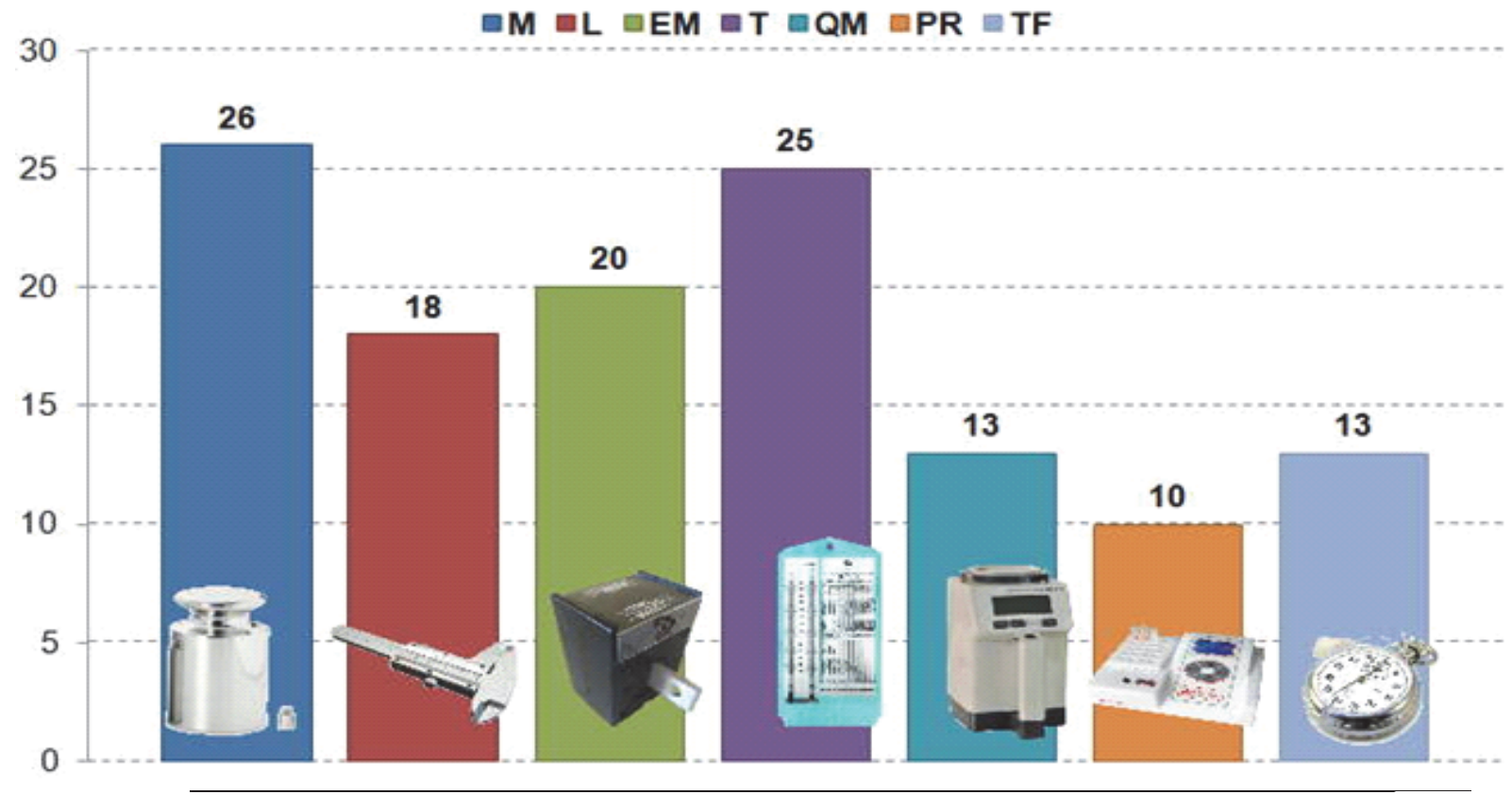

Рис. 6. Організації, що прийняли участь у раундах перевірки професійного рівня за видами вимірювань Джерело: розроблено авторами. 
Кількість Організацій, що приймали участь

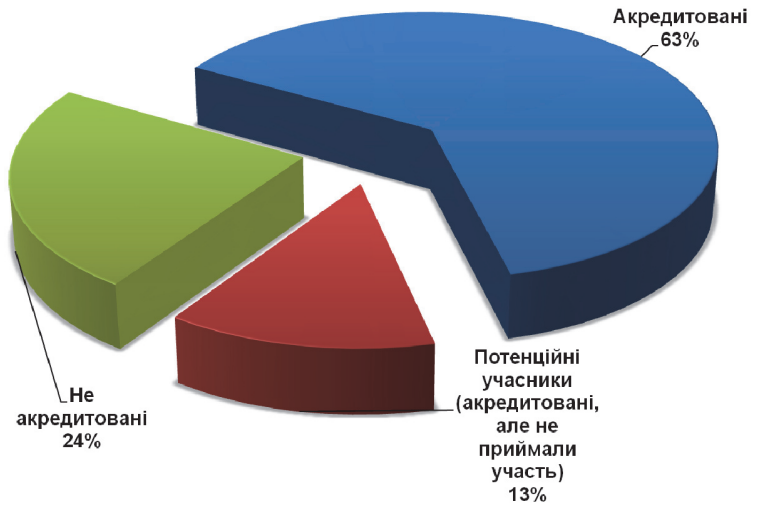

Рис. 7. Організації, що приймали у раундах перевірки професійного рівня Джерело: розроблено авторами.

Крім цього, участь у раундах прийняли одинадцять неакредитованих лабораторій, що свідчить про їх відповідальний підхід до зовнішнього контролю якості своєї професійної діяльності та, мабуть, про наявне бажання пройти процедуру акредитації.

На рис. 8 наведено узагальнені результати оцінки статистик робочих характеристик учасників раундів перевірки професійного рівня. Оцінювання статистик у різних раундах проводилась із застосуванням різних статистик, рекомендованих EN ISO/IEC 17043 [6] та ISO 13528 [11], а саме: кількісний $z$ '-показник, кількісний $z$-показник, число- вий показник $E_{\mathrm{n}}$. Інтерпретація статистик проводилась шляхом порівняння 3 критичними значеннями згідно з EN ISO/IEC 17043 [6] та ISO 13528 [11], на основі чого отримувалися висновки стосовно якості роботи учасників. Якість роботи учасників оцінювалась за трьома категоріями:

1) “задовільна" якість - запобіжні або коригувальні дії не потрібні;

2) "сумнівна" якість - необхідне виконання запобіжних дій;

3) “незадовільна" якість - вимагає виконання коригувальних дій.

Процентне відношення розрахованих статистик по відношенню до видів вимірювання наведено у табл. 2.

3 наведених даних випливає, що за всіма раундами було розраховано 1710 статистик, серед них вказують на:

1) “задовільну” якість роботи - $1670(97,7 \%)$;

2) “сумнівну” якість роботи - 4 (0,2\%);

$3)$ “незадовільну” якість роботи - 36 (2,1\%).

Найбільший відсоток “незадовільної” якості роботи виявлено у таких видах вимірювання:

1) ЕМ - засоби вимірювання електричних та магнітних величин (3,9\%);

2) $\mathrm{M}$ - засоби вимірювання маси та пов'язаних 3 нею величин (3,0\%);

3) Т - засоби вимірювання термометричних величин $(1,7 \%)$.

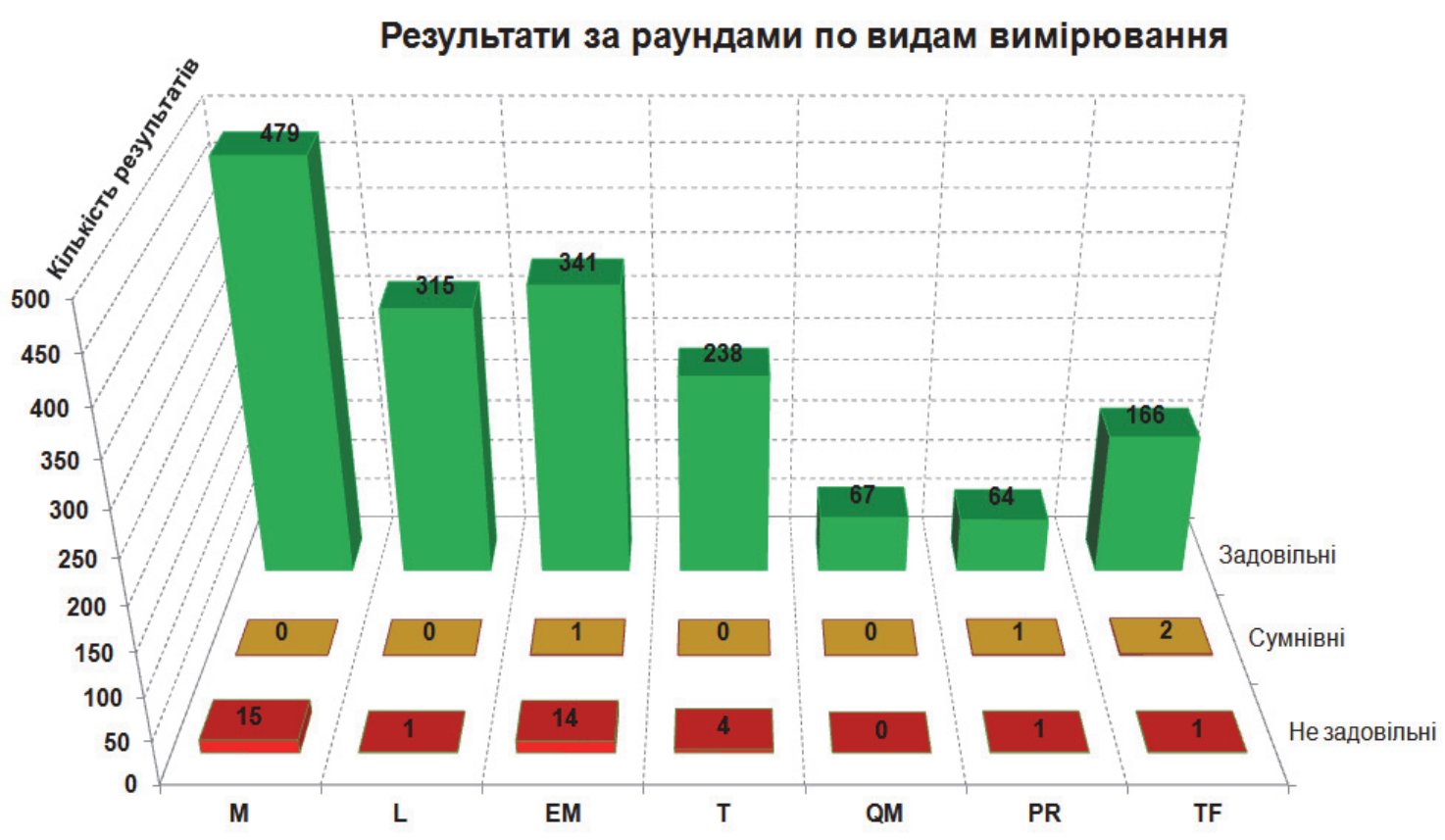

\begin{tabular}{|l|c|c|c|c|c|c|c}
\cline { 2 - 7 } \multicolumn{1}{c|}{} & $\mathrm{M}$ & $\mathrm{L}$ & $\mathrm{EM}$ & $\mathrm{T}$ & QM & PR & \multicolumn{1}{c|}{ TF } \\
\hline$\square$ Не задовільні & 15 & 1 & 14 & 4 & 0 & 1 \\
\hline$\square$ Сумнівні & 0 & 0 & 1 & 0 & 238 & 1 \\
\hline -Задовільні & 479 & 315 & 341 & 238 & 67 & 166 \\
\hline
\end{tabular}

Рис. 8. Узагальнені результати оцінки статистик робочих характеристик учасників Джерело: розроблено авторами за даними [9]. 
Таблиця 2

Статистики робочих характеристик учасників за видами вимірювання

\begin{tabular}{|c|c|c|c|c|}
\hline $\begin{array}{c}\text { Вид } \\
\text { вимірю- } \\
\text { вання }\end{array}$ & $\begin{array}{c}\text { Загальна } \\
\text { кількість } \\
\text { отри- } \\
\text { маних } \\
\text { сатистик }\end{array}$ & $\begin{array}{c}\text { на” якість } \\
\text { роботи }\end{array}$ & $\begin{array}{c}\text { якадість } \\
\text { роботи }\end{array}$ & $\begin{array}{c}\text { якововільна” } \\
\text { роботи }\end{array}$ \\
\hline $\mathrm{M}$ & 494 & $3,0 \%$ & $0,0 \%$ & $97,0 \%$ \\
\hline $\mathrm{L}$ & 316 & $0,3 \%$ & $0,0 \%$ & $99,7 \%$ \\
\hline $\mathrm{EM}$ & 356 & $3,9 \%$ & $0,3 \%$ & $95,8 \%$ \\
\hline $\mathrm{T}$ & 242 & $1,7 \%$ & $0,0 \%$ & $98,3 \%$ \\
\hline $\mathrm{QM}$ & 67 & $0,0 \%$ & $0,0 \%$ & $100,0 \%$ \\
\hline $\mathrm{PR}$ & 66 & $1,5 \%$ & $1,5 \%$ & $97,0 \%$ \\
\hline $\mathrm{TF}$ & 169 & $0,6 \%$ & $1,2 \%$ & $98,2 \%$ \\
\hline \hline Сумарно & 1710 & $2,1 \%$ & $0,2 \%$ & $97,7 \%$ \\
\hline
\end{tabular}

Джерело: розроблено авторами за даними [9].

Найбільший відсоток “задовільної” якості роботи виявлено у наступних видах вимірювання:

1) $\mathrm{QM}$ - засоби вимірювання фізико-хімічних величин та кількості речовини (100,0 \%);

2) L - засоби вимірювання довжини (99,7 \%);

3) $\mathrm{T}$ - засоби вимірювання термометричних величин (98,3 \%);

4) $\mathrm{TF}$ - засоби вимірювання часу та частоти $(98,2 \%)$.

Отримані оцінки якості роботи учасників вказують на в цілому “задовільну” якість роботи учасників $(97,7$ \%) та дають змогу стверджувати, що забезпечення єдності вимірювань в Україні серед калібрувальних лабораторій знаходиться на досить високому рівня, хоча і наявні деякі проблеми.

\section{Висновки}

Підсумовуючи все вище зазначене, можна зробити наступні висновки про діяльність першого в Україні провайдера перевірки професійного рівня МЦ ДП “Харківстандартметрологія”, акредитованого на відповідність EN ISO/IEC 17043 [6]:

1) наявних семи схем перевірки професійного рівня недостатньо для задоволення всіх потреб замовників, є необхідність у створенні, як мінімум, ще однієї схеми за видом вимірювання AUV - акустика, ультразвук і вібрація;

2) існуюча сфера акредитації провайдера МЦ ДП “Харківстандартметрологія” не задовольняє всіх потреб замовників та потребує розширення, як мінімум за тими напрямками, за якими вже проведені раунди;

3) збільшення кількості раундів та учасників, що спостерігається 3 роками, потребує вдосконалення інструментів та засобів автоматизації процедур провайдера перевірки професійного рівня для підвищення якості надаваних послуг;

4) досить велика кількість акредитованих та не акредитованих калібрувальних лабораторій свідчить про великий попит та довіру до надаваних послуг провайдера перевірки професійного рівня МЦ ДП "Харківстандартметрологія”;

5) узагальнені результати оцінки статистик робочих характеристик учасників раундів перевірки професійного рівня дають змогу стверджувати, що забезпечення єдності вимірювань в Україні серед калібрувальних лабораторій знаходиться на досить високому рівня, хоча і наявні деякі проблеми.

\section{Список літератури}

1. Коржов І. М. Перспективи розвитку теорії і практики контролю та діагностування в розрізі перевірки кваліфікації лабораторій. Вісник Національного технічного університету “ХПI”. 2018. № 27 (1303). С. 30-34.

2. Величко В. А. та ін. Перевірки професійного рівня оцінювання учасників на підставі аналізу калібрувальних кривих. Eurasian scientific congress : зб. тез доп. VIII міжнар. наук. практ. конф. Barcelona, Spain, 2020. C. 129-135.

3. Величко В. А., Коржов І. М., Новомодний О. М., Чепела В. М. Перевірка професійного рівня: калібрування колб мірних для медичних лабораторій. Украӥнський метрологічний журнал. 2020. № 3А. С. 118-123.

4. Коржов I. М., Новомодний О. М., Мигущенко Р. П. Перевірка професійного рівня: калібрування мегомметрів. Метрологія та прилади. 2020. № 5(85). С. 69-72.

5. Новомодный О. Н., Коржов И. М. Проверка профессионального уровня калибровочных лабораторий Метрологическим центром ГП “Харьковстандартметрология”. Радіоелектроніка та молодь у XXI столітті : зб. тез доп. XXV міжнар. наук. практ. конф. Харків : ХНУРЕ, 2021. Т. 4. С. 161-162.

6. EN ISO/IEC 17043:2010 Conformity assessment - General requirements for proficiency testing. [Publication date 2010-02]. Official publication. Geneva, Switzerland : ISO, 2010. $39 \mathrm{p}$

7. ISO/IEC 17025:2017 General requirements for the competence of testing and calibration laboratories. [Publication date 2017-11]. Official publication. Geneva, Switzerland : ISO, 2017. 30 p.

8. Політика НААУ щодо участі органів з оцінки відповідності у перевірках кваліфікації (ЗД-08.00.29:ред. 02). Наиіональне агентство з акредитаиіï України : веб-сайт. URL: https://naau.org.ua/english-polityka-naau-shhodo-uchastiorganiv-z-otsinky-vidpovidnosti-u-mizhlaboratornyh-porivnyannyah-ta-perevirkah-kvalifikatsiyi/ (дата звернення 01.04.2021).

9. Провайдер перевірки професійного рівня Метрологічний центр ДП “Харківстандартметрологія”. ДП “Харківстандартметрологія” : веб-сайт. URL: http://khsms.com/primaryactivity/metrology/about/type/remont/id/23 (дата звернення 01.04.2021). 
10. Реєстр акредитованих ООВ. Національне агентство з акредитаиії Украӥни : веб-сайт. URL: https://naau.org.ua/reyestr-akreditovanix-oov/ (дата звернення 01.04.2021).

11. ISO 13528:2015 Statistical methods for use in proficiency testing by interlaboratory comparison. [Publication date 2015-08]. Official publication. Geneva, Switzerland : ISO, 2015. 89 p.

12. ДСТУ EN ISO/IEC 17043:2014 Оцінка відповідності. Загальні вимоги до перевірки кваліфікації лабораторій. [Не чинний від 2018-01-01]. Вид. офіц. Київ : ДП “УкрНДНЦ”, 2014. 49 с.

13. ДСТУ EN ISO/IEC 17043:2017 (EN ISO/IEC 17043:2010; ISO/IEC 17043:2010, IDT) Оцінка відповідності. Загальні вимоги до перевірки професійного рівня. [Чинний від 2018-01-01]. Вид. офіц. Київ : ДП “УкрНДНЦ”, 2018. 39 с.

14. Gorkunov B., Lvov S., Borysenko Y. Uncertainty estimation while proceeding multi-parameter eddy current testing. Information Processing Systems. 2018. № 4(155). P. 92-97. https://doi.org/10.30748/soi.2018.155.12.

15. Дроздова Т. В. Аналіз похибок та невизначеності експертних оцінок. Інформаційні технології: наука, техніка, технологія, освіта, здоров'я : зб. тез доп. XXVI міжнар. наук. практ. конф. Харків : НТУ “ХПІ”, 2018. С. 23.

16. Захаров И. П., Водотыка С. В., Шевченко Е. Н. Методы, модели и бюджеты оценивания неопределенности измерений при проведении калибровок. Измерительная техника. № 4. С. 20-27.

17. Данилов А. А., Пименова Е. Ю., Тюрина Ю. Г. Практические вопросы формирования области аккредитации калибровочной лаборатории. Заводская лаборатория. Диагностика материалов. 2017. № 83(8). С. 73-76.

\section{Відомості про авторів:}

\section{Чепела Володимир Миколайович}

керівник провайдера перевірки професійного рівня заступник генерального директора з метрології Державного підприємства “Харківський регіональний науково-виробничий центр стандартизації, метрології та сертифікації” (ДП “Харківстандартметрологія”),

Харків, Україна

https://orcid.org/0000-0002-0352-6812

\section{Новомодний Олег Миколайович}

керівник координатора провайдера перевірки

професійного рівня, начальник відділу

Державного підприємства "Харківський регіональний науково-виробничий центр стандартизації, метрології та сертифікації” (ДП “Харківстандартметрологія”), Харків, Україна

https://orcid.org/0000-0001-5412-2589

\section{Коржов Ігор Михайлович}

кандидат технічних наук

технічний експерт провайдера перевірки професійного рівня, інженер з метрології II категорії

Державного підприємства "Харківський регіональний науково-виробничий центр стандартизації, метрології та сертифікаціі” (ДП “Харківстандартметрологія”),

Харків, Україна

https://orcid.org/0000-0003-2315-2683

\section{Колбасін Олександр Іванович}

кандидат технічних наук

технічний експерт провайдера перевірки професійного рівня, інженер з метрології I категорії

Державного підприємства “Харківський регіональний науково-виробничий центр стандартизації, метрології та сертифікаціі” (ДП “Харківстандартметрологія”), Харків, Україна

https://orcid.org/0000-0001-5429-8779

\section{Information about the authors: \\ Volodymyr Chepela}

Acting Head of Proficiency Testing Provider

Deputy Director General on Metrology

of State enterprise "Kharkov regional research and production center for standardization, metrology and certification" (SE "Kharkovstandartmetrology"), Kharkiv, Ukraine

https://orcid.org/0000-0002-0352-6812

\section{Oleh Novomodnyi}

Head of Coordinator of Proficiency Testing Provider Head of the Department

of State enterprise "Kharkov regional research and production center for standardization, metrology and certification" (SE "Kharkovstandartmetrology"), Kharkiv, Ukraine

https://orcid.org/0000-0001-5412-2589

\section{Ihor Korzhov}

$\mathrm{PhD}$ in Engineering

Technical Expert of Proficiency Testing Provider Metrology Engineer II Category

of State enterprise "Kharkov regional research and production center for standardization, metrology and certification" (SE "Kharkovstandartmetrology"), Kharkiv, Ukraine

https://orcid.org/0000-0003-2315-2683

\author{
Alexander Kolbasin \\ $\mathrm{PhD}$ in Engineering \\ Technical Expert of Proficiency Testing Provider \\ Metrology Engineer I Category \\ of State enterprise "Kharkov regional research \\ and production center for standardization, metrology \\ and certification" (SE "Kharkovstandartmetrology"), \\ Kharkiv, Ukraine \\ https://orcid.org/0000-0001-5429-8779
}




\title{
АНАЛИЗ ТЕКУЩЕГО СОСТОЯНИЯ И ДИНАМИКИ РАБОТ КАЛИБРОВОЧНЫХ ЛАБОРАТОРИЙ УКРАИНЫ
}

\author{
В.Н. Чепела, О.Н. Новомодный, И.М. Коржов, А.И. Колбасин
}

В статье приведены обобщенные результаты текущего состояния и динамики работ калибровочных лабораторий Украины. Рассмотрена деятельность Метрологического иентра Государственного предприятия "Харьковский региональный научно-производственный центр стандартизации, метрологии и сертификации” (МЦ ГП “Харьковстандартметрология") - первого в Украине аккредитованного на соответствие EN ISO/IEC 17043 провайдера проверки профессионального уровня. Приведень обобщенные результаты проверки профессионального уровня участников более ста раундов, в которых приняли участие более пятидесяти участников от более чем тридиати пяти организаций различной формы собственности. Проведен анализ структуры завершенных раундов и их участников по годам и видам измерений.

Ключевые слова: проверка профессионального уровня, провайдер проверки профессионального уровня, EN ISO/IEC 17043, калибровка.

\section{ANALYSIS OF THE CURRENT STATE AND DYNAMICS OF CALIBRATION LABORATORIES OF UKRAINE}

\author{
V. Chepela, O. Novomodnyi, I. Korzhov, A. Kolbasin
}

The article presents the generalized results of the current state and dynamics of calibration laboratories of Ukraine. The activity of the Metrological Center of the State Enterprise "Kharkiv Regional Research and Production Center for Standardization, Metrology and Certification" (MC SE "Kharkivstandartmetrologiya") - the first in Ukraine accredited for compliance with EN ISO/IEC 17043 proficiency testing provider.

In the past, some experience has been gained in the field of verification of the proficiency testing of calibration laboratories. There is a need for a detailed analysis of the current state and dynamics of work to verify the proficiency testing among the calibration laboratories of Ukraine. As of the first quarter of the year, four accredited proficiency testing provider inspections have been registered in Ukraine, among which the MC SE "Kharkivstandartmetrologiya" is the only one that specializes in conducting proficiency testing inspections of calibration laboratories. Other providers proficiency testing have the scope of accreditation related to the testing of various products. MC SE "Kharkivstandartmetrologiya" conducts rounds of proficiency testing verification schemes both in the field of its accreditation and outside the field, mastering new areas to meet the needs of customers of these services. The quality of work in the new areas is ensured by the application of approaches and requirements for the organization and conduct of proficiency testing, in accordance with the provisions and requirements of EN ISO/IEC 17043 and ISO 13528. The generalized results of the examination of the proficiency testing of the participants of more than one hundred rounds of participation, in which more than three hundred and fifty participants from more than thirty-five organizations of various forms of ownership took part, are presented. The analysis of the structure of completed rounds and their participants by years and types of measurements is carried out.

$M C S E$ "Kharkivstandartmetrologiya" invites everyone to cooperate in the field of professional verification in accordance with the requirements of EN ISO/IEC 17043

Keywords: proficiency testing, provider of proficiency testing, EN ISO/IEC 17043, calibration. 